|| ISSN(online): 2589-8698 || ISSN(print): 2589-868X || International Journal of Medical and Biomedical Studies

Available Online atwww.ijmbs.info

PubMed (National Library of Medicine ID: 101738825)

Index Copernicus Value 2018: 75.71

Original Research Article

Volume 3, Issue 7; July: 2019; Page No. 211-215

\title{
COMPARISON OF ESMOLOL, LABETALOL AND LIGNOCAINE FOR ATTENUATION OF SYMPATHOMIMETIC RESPONSES TO LARYNGOSCOPY AND ENDOTRACHEAL INTUBATION
}

\section{Dr. H. Kirankumar}

Associate Professor, Department of Anaesthesiology, Venkateshwara Institute of Medical Science, Gajraula, (U.P.)

Article Info: Received 23 June 2019; Accepted 24 July. 2019

DOI: https://doi.org/10.32553/ijmbs.v3i7.415

Address for Correspondence: Dr. H. Kirankumar, Associate Professor, Department of Anaesthesiology, Venkateshwara Institute of Medical Science, Gajraula, (U.P.)

Conflict of interest: Nil

\section{Abstract}

INTRODUCTION: In some individual's suffering from hypertension, coronary artery disease, cerebrovascular disease, myocardial infarction and thyrotoxicosis, these hemodynamic stress responses can turn into life-threatening conditions like left ventricular failure, myocardial ischemia, cerebral hemorrhage, and ruptured cerebral aneurysm. Different drugs like lidocaine, vasodilator agents inhibiting sympathoadrenal response, $\alpha$-and $\beta$-adrenergic blockers, and opioids can be administered prior to tracheal intubation to prevent hemodynamic responses. But higher dose of lignocaine may lead to hypotension, bradycardia, and hypoxia in patients. Due to various effect of these drugs on hemodynamic changes in patients this study was carried out to evaluate the effects of IV esmolol, lignocaine, and labetalol for attenuation of hemodynamic response to laryngoscopy and intubation.

MATERIAL AND METHODS: A total of 90 consecutive patients were included in the study and were grouped in to, lignocaine group, labetalol and esmolol group containing 30 patients each. Age group 21-65 years of either sex or American Society of Anesthesiologists (ASA) Grade I or II scheduled for various general surgical procedures under endotracheal anesthesia were included in this study. Patients excluded were pregnant and lactating women, morbid obesity, and hypertension.

RESULTS: Mean Age in Group 1, group2 and group 3 was $40.38 \pm 7.25,43.8 \pm 9.24$ and $42.56 \pm 8.71$ respectively while weight was $62.41 \pm 7.32,63.63 \pm 8.11$ and $60.74 \pm 6.92$ respectively. There were 17 male and 13 female in group 1,19 male and 11 female in group 2 and 16 male and 14 female in group 3. Attenuation of blood pressure was more in labetalol group. Reduction of heart rate in labetalol group was significant. It is seen that Labetalol was more effective at attenuation of diastolic blood pressure among all drugs. Mean arterial pressure was not much reduced lignocaine and esmolol group as compared to labetalol.

CONCLUSION: Haemodynamic alterations are usually observed during laryngoscopy and endotracheal intubation. In our study it was found that as labetalol is a safe and effective drug, for attenuation of sympathomimetic response.

\section{INTRODUCTION}

Rigid laryngoscopy and tracheal intubation is still the gold standard in airway management. Hemodynamic changes due are due to sympthoadrenal discharge caused by epipharyngeal and parapharyngeal stimulations ${ }^{i}$ which manifest as hypertension, tachycardia, and increase in serum catecholamine and this response is transient occurring 30 seconds after intubation and lasting for less than 10 minutes ii. In some individuals suffering from hypertension, coronary artery disease, cerebrovascular disease, myocardial infarction and thyrotoxicosis, these hemodynamic stress responses can turn into lifethreatening conditions like left ventricular failure, myocardial ischemia, cerebral hemorrhage, and ruptured cerebral aneurysm ${ }^{\text {iii iv }}$.

Different drugs like lidocaine, vasodilator agents inhibiting sympathoadrenal response, $\alpha$-and $\beta$ adrenergic blockers, and opioids can be administered prior to tracheal intubation to prevent hemodynamic responses ${ }^{v}$. Esmolol is an ultrashort-acting $\beta 1$ cardio selective $\beta$ blocking agent with a short half-life of about 9 minutes and this agent is used to reduce the increase in heart rate and blood pressure in response to tracheal intubation ${ }^{\mathrm{vi}}$. Labetalol has good response in attenuating the response to laryngoscopy and intubation and also in preventing preoperative cardiovascular event ${ }^{\text {vii }}$. 
Intravenous (IV) lignocaine has showed good result. The mechanism of IV local lignocaine appears to result from an increased threshold for airway stimulation and central inhibition of sympathetic transmission. But higher dose of lignocaine may lead to hypotension, bradycardia, and hypoxia in patients, viii.

Due to various effect of these drugs on hemodynamic changes in patients this study was carried out to evaluate the effects of IV esmolol, lignocaine, and labetalol for attenuation of hemodynamic response to laryngoscopy and intubation.

\section{MATERIAL AND METHODS}

Present study was carried out in the Department of Anaesthesiology at Venkateshwara Institute of Medical Science, Gajraula. A total of 90 consecutive patients were included in the study and were grouped in to, lignocaine group, labetalol and esmolol group containing 30 patients each. Age group 21-65 years of either sex or American Society of Anesthesiologists (ASA) Grade I or II scheduled for various general surgical procedures under endotracheal anesthesia were included in this study. Patients excluded were pregnant and lactating women, morbid obesity, and hypertension.

Patients completeclinical history, airway assessment, systemic examination along with routine blood investigations, chest $\mathrm{X}$-ray, and electrocardiogram (ECG) was carried out. All patients were given $500 \mathrm{ml}$ ringer lactate before starting induction. Blood pressure monitor, pulse oxymeter, 5 leads ECG were connected and basal pulse rate, systolic blood pressure (SBP), diastolic blood pressure (DBP) and mean blood pressure (MBP) were measured and recorded.

Before intubation study drug was given 5 min over 60 s. doses of study drug was esmolol $\mathrm{HCl} 0.5 \mathrm{mg} / \mathrm{kg}$ body weight diluted to $10 \mathrm{ml}$ with $0.9 \%$ saline was given IV $5 \mathrm{~min}$ before intubation over $60 \mathrm{~s}$, labetalol $\mathrm{HCl} 0.25 \mathrm{mg} / \mathrm{kg}$ body weight diluted to $10 \mathrm{ml}$ with $0.9 \%$ saline was given IV 5 min before intubation over $60 \mathrm{~s}$ and Injection lignocaine $\mathrm{HCl} 1 \mathrm{mg} / \mathrm{kg}$ body weight diluted to $10 \mathrm{ml}$ with $0.9 \%$ saline was given IV $5 \mathrm{~min}$ before intubation over $60 \mathrm{~s}$.

Readings of hemodynamic parameters were taken before starting study drug and was taken as basal value (BV) and then during laryngoscopy \& endotracheal intubation (DL). Three more readings were taken at $1 \mathrm{~min}, 5 \mathrm{~min}$ and $10 \mathrm{~min}$ of intubation.

Statistical analysis was carried out using SPSS software. Data were presented as mean + standard deviation. Demographic data were analysed for study.

\section{RESULTS}

A total of 90 patients were included in the study and randomly divided into 3 groups of 30 patients each Grroup1: lignocaine, Group 2: Labetolol and group 3: Esmolol. Mean Age in Group 1, group2 and group 3 was $40.38 \pm 7.25,43.8 \pm 9.24$ and $42.56 \pm 8.71$ respectively while weight was $62.41 \pm 7.32,63.63 \pm$ 8.11 and $60.74 \pm 6.92$ respectively.

Table 1: Demographic variables in groups

\begin{tabular}{|l|l|l|l|}
\hline & $\begin{array}{l}\text { Group 1 } \\
\text { (lignocaine) }\end{array}$ & $\begin{array}{l}\text { Group2 } \\
\text { (Labetalol) }\end{array}$ & $\begin{array}{l}\text { Group 3 } \\
\text { (Esmolol) }\end{array}$ \\
\hline Parameters & Group 1 & Group 2 & Group 3 \\
\hline Age & $40.38 \pm 7.25$ & $43.8 \pm 9.24$ & $42.56 \pm 8.71$ \\
\hline Weight & $62.41 \pm 7.32$ & $63.63 \pm 8.11$ & $60.74 \pm 6.92$ \\
\hline
\end{tabular}

Table 2: Distribution according to gender

\begin{tabular}{|l|l|l|l|l|}
\hline Sex & Group 1 & Group 2 & Group 3 & p - value \\
\hline Male & 17 & 19 & 16 & \multirow{2}{*}{0.72} \\
\cline { 1 - 4 } Female & 13 & 11 & 14 & \\
\hline
\end{tabular}

There were 17 male and 13 female in group 1, 19 male and 11 female in group 2 and 16 male and 14 female in group 3 . These results were statistically insignificant.

Table 3: Comparison of mean systolic blood pressure in different groups

\begin{tabular}{|c|c|c|c|}
\hline & Group 1 & Group 2 & Group 3 \\
\hline Basal value & $123.03 \pm 6.91$ & $121.94 \pm 7.13$ & $120.67 \pm 7.01$ \\
\hline $\begin{array}{c}\text { During } \\
\text { laryngoscopy }\end{array}$ & $138.26 \pm 12.96$ & $127.64 \pm 10.04$ & $132.79 \pm 9.68$ \\
\hline Al 1 & $136.57 \pm 10.98$ & $124.31 \pm 9.17$ & $130.52 \pm 8.79$ \\
\hline Al 5 & $134.66 \pm 10.25$ & $121.14 \pm 6.93$ & $128.16 \pm 6.04$ \\
\hline Al 10 & $132.98 \pm 11.23$ & $120.06 \pm 8.21$ & $126.94 \pm 7.19$ \\
\hline
\end{tabular}


Dr. H. Kirankumar, International Journal of Medical and Biomedical Studies(IJMBS)

\begin{tabular}{|l|l|l|}
\hline \multicolumn{2}{|l|}{$p$ - value } & \multicolumn{2}{|l|}{} \\
\hline Group 1 vs Group 2 & Group 2 vs Group 3 & Group 3 vs Group 1 \\
\hline 0.55 & 0.55 & 0.19 \\
\hline 0.0008 & 0.0691 & 0.0477 \\
\hline$<0.0001$ & 0.0096 & 0.0219 \\
\hline$<0.0001$ & 0.0001 & 0.0041 \\
\hline$<0.0001$ & 0.016 & 0.001 \\
\hline & & \\
\hline
\end{tabular}

In the study groups it is observed that there was statistically significant difference between Lignocaine, labetalol and esmolol after intubation. Attenuation of blood pressure was more in labetalol group.

Table 4: Comparision of mean heart rate in different groups

\begin{tabular}{|l|l|l|l|}
\hline \multirow{2}{*}{ Recording time } & \multicolumn{2}{|l|}{ Mean \pm SD } \\
\cline { 2 - 4 } & Group 1 & Group 2 & Group 3 \\
\hline Basal value & $98.20 \pm 10.98$ & $97.69 \pm 8.02$ & $97.12 \pm 9.87$ \\
\hline $\begin{array}{l}\text { During } \\
\text { laryngoscopy }\end{array}$ & $110.87 \pm 9.15$ & $102.87 \pm 8.13$ & $109.01 \pm 9.34$ \\
\hline $\begin{array}{l}\text { 1 min After } \\
\text { intubation }\end{array}$ & $110.03 \pm 10.51$ & $100.64 \pm 7.84$ & $107.38 \pm 8.13$ \\
\hline $\begin{array}{l}\text { 5 min After } \\
\text { intubation }\end{array}$ & $104.69 \pm 10.72$ & $97.38 \pm 6.77$ & $102.9 \pm 4.01$ \\
\hline $\begin{array}{l}\text { 1o min After } \\
\text { intubation }\end{array}$ & $100.87 \pm 8.69$ & $97.54 \pm 6.98$ & $100.1 \pm 5.99$ \\
\hline
\end{tabular}

\begin{tabular}{|l|l|l|}
\hline \multicolumn{2}{|l|}{$p$ - value } \\
\hline Group 1 vs Group 2 & Group 2 vs Group 3 & Group 3 vs Group 1 \\
\hline 0.8379 & 0.6901 & 0.8069 \\
\hline 0.0007 & 0.0087 & 0.4391 \\
\hline 0.0002 & 0.0018 & 0.2792 \\
\hline 0.0025 & 0.0003 & 0.3952 \\
\hline 0.1072 & 0.1328 & 0.6909 \\
\hline
\end{tabular}

Among all groups in present study it is found that there was statistically significant difference between Lignocaine, labetalol and esmolol after intubation. Reduction of heart rate in labetalol group was significant.
Table 5: Comparison of mean diastolic blood pressure

\begin{tabular}{|l|l|l|l|}
\hline \multirow{2}{*}{$\begin{array}{l}\text { Recording } \\
\text { time }\end{array}$} & \multicolumn{3}{|l|}{ Mean \pm SD } \\
\cline { 2 - 4 } & Group 1 & Group 2 & Group 3 \\
\hline Basal value & $80.01 \pm 5.71$ & $77.92 \pm 3.05$ & $77.25 \pm 6.84$ \\
\hline $\begin{array}{l}\text { During } \\
\text { laryngoscopy }\end{array}$ & $93.23 \pm 11.63$ & $87.24 \pm 8.11$ & $88.46 \pm 10.53$ \\
\hline Al 1 & $90.88 \pm 12.27$ & $84.92 \pm 6.21$ & $87.15 \pm 8.24$ \\
\hline Al 5 & $88.17 \pm 11.93$ & $84.10 \pm 7.03$ & $86.42 \pm 6.02$ \\
\hline Al 10 & $86.91 \pm 10.35$ & $82.37 \pm 9.29$ & $85.66 \pm 7.78$ \\
\hline
\end{tabular}

\begin{tabular}{|l|l|l|}
\hline \multicolumn{3}{|l|}{$p$ - value } \\
\hline Group 1 vs Group 2 & Group 2 vs Group 3 & Group 3 vs Group 1 \\
\hline 0.0823 & 0.626 & 0.0951 \\
\hline 0.0242 & 0.617 & 0.1012 \\
\hline 0.0209 & 0.2413 & 0.1722 \\
\hline 0.1129 & 0.1751 & 0.4761 \\
\hline 0.079 & 0.1424 & 0.599 \\
\hline
\end{tabular}

In present study it is seen that Labetalol was more effective at attenuation of diastolic blood pressure among all drugs.

Table 6: Comparision of mean arterial pressure among different groups

\begin{tabular}{|l|l|l|l|}
\hline \multirow{2}{*}{ Recording time } & \multicolumn{2}{|l|}{ Mean \pm SD } \\
\cline { 2 - 4 } & Group 1 & Group 2 & Group 3 \\
\hline Basal value & $94.65 \pm 6.02$ & $93.98 \pm 3.84$ & $93.16 \pm 5.54$ \\
\hline During laryngoscopy & $108.77 \pm 10.14$ & $101.21 \pm 7.77$ & $104.14 \pm 8.91$ \\
\hline Al 1 & $107.12 \pm 10.59$ & $97.56 \pm 6.02$ & $101.98 \pm 8.24$ \\
\hline Al 5 & $103.78 \pm 11.24$ & $96.31 \pm 7.41$ & $100.54 \pm 5.11$ \\
\hline Al 10 & $102.22 \pm 10.28$ & $95.43 \pm 8.21$ & $100.16 \pm 7.09$ \\
\hline
\end{tabular}

\begin{tabular}{|l|l|l|}
\hline$p$ - value \\
\hline Group 1 vs Group 2 & Group 2 vs Group 3 & Group 3 vs Group 1 \\
\hline 0.6092 & 0.5079 & 0.3226 \\
\hline 0.002 & 0.1799 & 0.06 \\
\hline 0.0001 & 0.021 & 0.0403 \\
\hline 0.0036 & 0.0152 & 0.156 \\
\hline 0.0064 & 0.0202 & 0.37 \\
\hline
\end{tabular}


It is observed that mean arterial pressure was not muchreduced lignocaine and esmolol group as compared to labetalol.

\section{DISCUSSION}

Laryngeal and tracheal tissues stimulus causes increase in sympathetic and sympathoadrenal reflex activity $^{\text {ix }}$. Lidocaine, vasodilator agents inhibiting sympathoadrenal response, $\alpha$ and $\beta$ adrenergic blockers, and opioids can be administered prior to tracheal intubation in order to prevent haemodynamic responses ${ }^{4}$. Authors have reporedt the circulatory response to laryngeal and tracheal stimulation in anaesthetized man as tachycardia and increase in arterial blood pressure ${ }^{x}$.

In our study baseline parameters were matched in all three groups and didn't show any significant difference after intubation. No significant difference was observed in baseline systolic blood pressure and heart rate.

Our study showed that esmolol, given 5 min before intubation is significantly less effective attenuation of heart rate as compared to labetalol group. In a study by Gupta $S$ et al ${ }^{\mathrm{xi}}$. esmolol $2 \mathrm{mg} / \mathrm{kg}$ as a bolus dose proved to be effective in attenuating increases in heart rate.

In our study it is observed that there was statistically significant difference between Lignocaine, labetalol and esmolol after intubation. Attenuation of systolic blood pressure was more in labetalol group in concordance to a study where the change in mean SBP was most effectively attenuated by labetalol followed by esmolol, whereas lignocaine showed least attenuation effect among the three study drugs $\mathrm{s}^{\mathrm{xii}}$.

Among all groups in present study it is found that there was statistically significant difference between Lignocaine, labetalol and esmolol after intubation. Reduction of heart rate in labetalol group was significant. In a study by Kumar A et.al. it was noted that there was no statistically significant difference between labetalol and esmolol group at different time intervals ${ }^{\text {xiii. }}$.

In present study it is seen that Labetalol was more effective at attenuation of diastolic blood pressure among all drugs. It is observed that mean arterial pressure was not much reduced lignocaine and esmolol group as compared to labetalol. In a study by Kewalramani et al., it was observed on comparison of labatelol with dexmedetomidine, that dexmedetomidine better attenuated the sympathomimetic responses to endotracheal intubation and labetalol had maintained the stability of the blood pressure, heart rate response was not attenuated better during laryngoscopy and intubation $^{\text {xiv }}$.

\section{CONCLUSION:}

Haemodynamic alterations are usually observed during laryngoscopy and endotracheal intubation. In our study it was found that as compared to esmolol and lignocaine, labetalol is an safe and effective drug, for attenuation of sympathomimetic response.

\section{REFERENCES}

1. Singh SP, Quadir A, Malhotra P. Comparison of esmolol and labetalol, in low doses, for attenuation of sympathomimetic response to laryngoscopy and intubation. Saudi J Anaesth. 2010;4:163-8

2. Stoelting RK. Circulatory changes during direct laryngoscopy and tracheal intubation: Influence of duration of laryngoscopy with or without prior lidocaine. Anesthesiology. 1977;47:381-4.

3. Fox EJ, Sklar GS, Hill CH, Villanueva R, King BD. Complications related to pressor response to endotracheal intubation. Anaesthesiol. 1977;47:524-5

4. Prys-Roberts C, Foëx P, Biro GP, Roberts JG. Studies of anaesthesia in relation to hypertension. $V$. Adrenergic beta-receptor blockade. $\mathrm{Br} J$ Anaesth. 1973;45:67181.

5. Kumar A, Mishra PK, Shukla S. A randomized, controlled study to compare the effects of intravenous labetalol and esmolol on haemodynamic changes during laryngoscopy and intubation. Int J Res Med Sci 2017;5:4003-7.

6. Wolman RL, Fiedler MA. Esmolol and beta-adrenergic blockade. AANA J. 1991;59:541-8

7. Chung KS, Sinatra RS, Chung JH. The effect of an intermediate dose of labetalol on heart rate and blood pressure response to laryngoscopy and intubation. J ClinAnesth. 1992;4:11-5

8. Laurito $\mathrm{CE}$, Baughman VL, Becker GL, Polek WV, Riegler FX, VadeBoncouer TR. Effects of aerosolized and/or intravenous lidocaine on hemodynamic responses to laryngoscopy and intubation in outpatients. AnesthAnalg. 1988;67:389-92.

9. Kovac AL, Goto H, Arakawa K, Pardo MP. Esmolol bolus and infusion attenuates increases in blood pressure and heart rate during electroconvulsive therapy. Can J Anaesth. 1990;37(1):58-62

10. Reid LC, Brace DE. Intubation of respiratory tract and its reflex effect upon heart. SurgGynecol Obstet. 1940;70:157-62. 
11. Gupta S, Tank P. A comparative study of efficacy of esmolol and fentanyl for pressure attenuation during laryngoscopy and endotracheal intubation. Saudi J Anaesth. 2011;5:2-8.

12. Ratnani E, Sanjeev OP, Singh A, Tripathi M, Chourasia HK. A Comparative Study of Intravenous Esmolol, Labetalol and Lignocaine in Low Doses for Attenuation of Sympathomimetic Responses to Laryngoscopy and Endotracheal Intubation. Anesth Essays Res. 2017;11(3):745-750.

13. Kumar A, Mishra PK, Shukla S. A randomized, controlled study to compare the effects of intravenous labetalol and esmolol on haemodynamic changes during laryngoscopy and intubation. Int J Res Med Sci 2017;5:4003-7.

14. Kewalramani A, Partani S, Sharma NP, Sharma V. Comparison of labetalol versus dexmedetomidine to assess the haemodynamic responses to laryngoscopy and intubation during induction of general anaesthesia - A prospective, randomized, controlled study. Indian J ClinAnaesth. 2016;3:512-7. 